MP-23

\title{
IDENTIFIKASI MISKONSEPSI MAHASISWA PENDIDIKAN MATEMATIKA DENGAN MENGGUNAKAN METODE CRI (CERTANTY OF RESPONSE INDEX) PADA MATERI EKOLOGI MATA KULIAH BIOLOGI
}

\author{
${ }^{1}$ Maria Waldetrudis Lidi, ${ }^{2}$ Maria Fatima Mei ${ }^{3}$ Maria Trisna Sero Wondo \\ ${ }^{1,2,3}$ Program Studi Pendidikan Matematika Universitas Flores Ende \\ Email: ${ }^{1}$ waldetrudismaria1024@gmail.com,${ }^{2}$ imei60970@gmail.com, ${ }^{3}$ trisnawondo@gmail.com
}

\begin{abstract}
Abstrak
Penelitian ini bertujuan untuk mengetahui miskonsepsi mahasiswa pendidikan matematika Universitas Flores pada konsep-konsep ekologi. Jenis penelitian ini adalah penelitian deskriptif dengan satu variable yaitu miskonsepsi pada konsep-konsep ekologi.Analisis data dilakukan dengan mengidentifikasi data ke dalam kategori miskonsepsi (M), paham konsep (PK), paham konsep tapi kurang yakin (PKKY), dan tidak tahu konsep (TTK) kemudian dilihat persentase untuk masing-masing kategori pada setiap indikator.Hasil penelitian ini adalah sebagian besar mahasiswa matematika mengalami miskonsepsi pada konsep-konsep ekologi dengan rata-rata persentasi mahasiswa yang mengalami miskonsepsi sebesar 51,95\%, tidak tahu konsep sebesar 38,28, paham konsep sebesar 10,34\%, dan paham konsep tapi kurangyakinsebesar 9,49\%. Sebagian besar konsep-konsep yang diujikan memberikan dampak kuat pada miskonsepsi, diantaranya ekosistem dan komponennya, interaksi dalam ekosistem dan kaitannya dengan keseimbangan lingkungan, aliran energi dan kaitannya dengan keseimbangan lingkungan serta pemecahan masalah kerusakan lingkungan dengan pendekatan konsep-konsep ekologi.
\end{abstract}

\section{Kata kunci: Miskonsepsi, CRI}

\section{PENDAHULUAN}

Ilmu pengetahuan menjadi bermanfaat apabila dapat diterapkan dalam kehidupan untuk menunjang kehidupan, meningkatkan taraf hidup dan membantu mengatasi berbagai permasalahan yang dihadapi. Akan tetapi, hal ini masih menjadi tantangan mengingat ilmu pengetahuan hanya dikuasai sebatas menghafal saja. Kesulitan dalam mengaplikasikan ilmu yang diperoleh dalam kehidupan, ditemukan juga pada peserta didik pada tingkat perguruan tinggi.

Berdasarkan hasil observasi dan analisis angket yang dilakukan pada mahasiswa pendidikan matematika Universitas Flores, diketahui bahwa pada umumnya mahasiswa kesulitan untuk menghubungkan pengetahuan yang diperolehnya dengan penerapan dalam kehidupannya. Pemecahan masalah umumnya difokuskan pada bidang matematika dengan sedikit bahkan tanpa mengaitkan dengan bidang ilmu yang lain. Faktanya, masalah yang dialami oleh masyarakat tidak hanya sebatas pada masalah hitungan semata. Masalah dalam kehidupan juga membutuhkan disiplin ilmu sains lain dalam pemecahannya, seperti biologi, kimia dan fisika.

Makalah dipresentasikan dalam Seminar Nasional Pendidikan Dasar dengan tema " Inovasi Pembelajaran menyenangkan di Tingkat Pendidikan Dasar " pada tanggal 2 Desember 2017 di Program Studi PGSD Universitas Flores Ende. 
Mata kuliah biologi dasar adalah mata kuliah jurusan yang wajib diprogramkan oleh mahasiswa semester satu pada program studi pendidikan matematika. Manusia adalah makhluk hidup dengan segala kompleksitas masalah yang mengiringinya, oleh karena itu sudah tentu pembelajar matematika juga membutuhkan biologi dalam mempelajari kehidupan itu sendiri termasuk dirinya sendiri sehingga dapat memecahkan masalah-masalah kehidupan yang dihadapinya. Biologi dipandang sebagai ilmu yang mudah untuk dikuasai karena mengutamakan hafalan untuk mempelajarinya sedangkan matematika sebaliknya.Hal tersebut menyebabkankonsep-konsep biologi tidak dikuasai atau dikuasai tanpa dipahami atau miskonsepsi.

Manusia membentuk pemahamannya atau gagasannya akibat interaksinya dengan alam sebelum mereka mempelajarinya di sekolah, pemahaman ini disebut prakonsepsi (Ibrahim (2012); Laksana (2016)). Prakonsepsi dapat sesuai dengan konsep ilmiah yang diakui ilmuwan dapat juga tidak. Prakonsepsi yang tidak sesuai dengan kebenaran ilmiah inilah yang disebut miskonsepsi atau salah konsep. Menurut Tayubi (2005) dan Murni (2013), miskonsepsi adalah suatu konsepsi yang menyimpang dari konsepsi para ahli, melekat kuat pada diri orang tersebut dan berdampak menyesatkan dalam mengakomodasi pengetahuan. Ditambahkan oleh Ibrahim (2012), jika prakonsepsi yang tidak sesuai diperbaiki ke konsep yang benar, tetapi orang tersebut kembali lagi pada prakonsepsi sebelumnya maka ini disebut miskonsepsi. Miskonsepsi disebabkan oleh beberapa hal yakni siswa, guru, buku teks, konteks, dan metode mengajar (Muna (2015); Munawaroh, Falahi (2016)). Menurut Tayubi dan Murni (2013), miskonsepsi terjadi ketika siswa salah menginterpretasi gejala alam/peristiwa yang dialaminya dalam interaksi dengan lingkungannya.

Miskonsepsi berdampak negatif pada pembelajaran, seperti mengganggu perolehan konsep yang benar, rendahnya hasil belajar, ketidakmampuan dalam memecahkan masalah-masalah kontekstual, dan menghambat perolehan konsep baru. Lebih memprihatinkan, apabila miskonsepsi tersebut terdapat pada calon guru karena jika kesalahan konsep ini tetap dibiarkan maka akan menjadi mata rantai kesalahan konsep yang diwariskan secara turun temurun. Terdapat beberapa cara yang dapat digunakan untuk mengidentifikasi miskonsepsi diantaranya adalah, peta konsep, tes diagnostik melalui tes tertulis dan memberi alasan terbuka, tes esai tertulis, wawancara diagnosis, diskusi dalam kelas, hingga praktikum tanya jawab (Suparno, 2005 dalam Mustaqim, Zulfiani, Herlanti, 2014).

Selain metode di atas, terdapat metode lain yang dapat digunakan untuk mengidentifikasi kesalahan konsep yakni metode CRI (Certainty Of Response Index) yang dikembangkan oleh Saleem, H dkk. Teknik ni digunakan untuk mengidentifikasi mahasiswa yang paham konsep, 
tidak paham konsep dan yang mengalami miskonsepsi. CRI biasanya didasarkan pada suatu skala dan diberikan bersamaan dengan setiap jawaban suatu soal. Tingkat kepastian jawaban tercermin dalam skala CRI yang diberikan, CRI yang rendah menandakan ketidakyakinan konsep pada diri responden dalam menjawab suatu pertanyaan, dalam hal ini jawaban biasanya ditentukan atas dasar tebakan semata.Sebaliknya CRI yang tinggi mencerminkan keyakinan dan kepastian konsep yang tinggi pada diri responden dalam menjawab pertanyaan, dalam hal ini unsure tebakan sangat kecil. Seorang responden mengalami miskonsepsi atau tidak tahu konsep dapat dibedakan secara sederhana dengan cara membandingkan benar tidaknya jawaban suatu soal dengan tinggi rendahnya indeks kepastian jawaban (CRI) yang diberikannya untuk soal tersebut. CRI biasanya didasarkan pada suatu skala yaitu skala enam (0-5) (Saleem, 1999: 297) seperti pada Tabel 1 berikut:

Tabel 1.SkalaRespon Certainty of Response Index (CRI)

\begin{tabular}{cl} 
CRI & Kriteria \\
& \\
\hline 0 & (Totally guessed answer jika menjawab soal 100\% ditebak \\
1 & (Almost guess) jika menjawab soal presentase unsure tebak antara $75 \%-99 \%$ \\
2 & (Not sure) jika menjawab soal presentase unsure tebak antara 50\%-74\% \\
3 & (Sure) jika menjawab soal presentase unsure tebak antara 25\%-49\% \\
4 & (Almostcertain)jikamenjawabsoalpresentaseunsurtebakantara 1\%-24\% \\
& (certain)jikamenjawabsoaltidakadaunsurtebakansamasekali (0\%) \\
\hline
\end{tabular}

Berdasarkan tabel tersebut, skala CRI ada 6 (0-5) dimana 0 berarti tidak tahu konsep skema sama sekali tentang konsep-konsep yang diperlukan untuk mejawab suatu pertanyaan (jawaban secara total), sementara angka 5 menandakan kepercayaan diri yang penuh atas kebenaran pengetahuan tentang prinsip-prinsip, hukum-hukum, aturan-aturan yang digunakan untuk menjawab suatu pertanyaan (soal), tidak ada unsur tebakan sama sekali. Jika derajat keyakinan rendah (nilai CRI 0-2) menyatakan bahwa respon menjawab dengan cara menebak, terlepas dari jawaban benar atau salah.Hal ini menunjukkan bahwa responden tidak paham konsep.

Jika nilai CRI tinggi, dan jawaban benar maka menunjukan bahwa responden paham konsep (jawabannya berhasil).Jika nilai CRI tinggi, jawaban salah maka menunjukkan miskonkonsepsi. Jadi, seorang siswa mengalami miskonsepsi atau tidak paham konsep dapat dibedakan dengan cara sederhana yaitu dengan membandingkan benar atau tidaknya jawaban suatu soal dengan tinggi rendahnya indeks kepastian jawaban (CRI) yang diberikan untuk soal tersebut. Adapun ketentuan CRI untuk membedakan tahu konsep, miskonsepsi, dan tidak paham konsep. 
Tabel 2.CRI UntukMembedakanTahuKonsep, Miskonsepsi, danTidakPahamKonsep

\begin{tabular}{ccc}
\hline $\begin{array}{c}\text { Kriteria } \\
\text { Jawaban }\end{array}$ & CRI Rendah $^{(>2,5)}$ & CRI tinggi $(>2,5)$ \\
\hline Jawaban Benar & $\begin{array}{c}\text { Jawaban benar tapi CRI rendah } \\
\text { berarti tidak tahu konsep (lucky } \\
\text { guess) }\end{array}$ & $\begin{array}{c}\text { Jawabanbenar CRI tinggi berarti } \\
\text { menguasi konsep dengan baik }\end{array}$ \\
$\begin{array}{c}\text { Jawaban Salah } \\
\text { Jawaban salah dan CRI rendah } \\
\text { berarti tidak tahu konsep }\end{array}$ & $\begin{array}{c}\text { Jawabansalahtapi CRI tinggi berarti } \\
\text { terjadi miskonsepsi }\end{array}$ \\
\hline
\end{tabular}

Berdasarkan tabel 2 di atas menunjukkan empat kemungkinan kombinasi dari jawaban (benar atau salah) dan CRI (tinggi atau rendah) untuk tiap responden secara individu.Untuk seorang responden dan untuk suatu pertanyaan yang diberikan, jawaban benar dengan CRI rendah menandakan tidak tahu konsep, dan jawaban benar dengan CRI tinggi menunjukkan penguasaan konsep yang tinggi. Jawaban salah dengan CRI rendah menandakan tidak tahu konsep, sementara jawaban salah dengan CRI tinggimenandakan terjadinya miskonsepsi.

\section{METODE PENELITIAN}

Jenis penelitian adalah penelitian deskriptif dengan satu variable yaitu miskonsepsi pada konsep-konsep ekologi.Penelitianinidilakukan di kelas A dankelas B mahasiswa semester 1 Program Studi Pendidikan Matematika Universitas Flores tahun akademik 2017/2018 pada bulan September 2017. Jumlah mahasiswa dari dua kelas tersebut adalah 44 orang.

Instrumen yang digunakan dalam penelitian ini adalah instrumen tes berupa tes pilihan ganda dengan empat pilihan. Tes ini dijawab seperti tes pilihan ganda biasanya tetapi ditambahkan dengan membubuhkan angka $0,1,2,3,4$, atau 5 sesuai dengan tingkat kepercayaan pada jawaban yang telah diberikan. Angka inilah yang disebut dengan CRI. Instrumen tes yang disusun merupakan instrumen konsep-konsep ekologi. Data yang diambil adalah data yang berasal dari instrumen tes.

Teknik pengumpulan data dalam penelitian ini adalah teknik tes diagnostik. Data yang diperoleh dalam penelitian ini kemudian diidentifikasikan ke dalam kategori Miskonsepsi (M), Paham Konsep (PK), Paham Konsep tapi Kurang Yakin (PKKY), danTidak Tahu Konsep (TTK), yang kemudian dilihat persentase untuk masing-masing kategori pada setiap indicator dengan mengikuti langkah-langkahsebagai berikut:1) Melakukan penskoran dan tabulasi indeks CRI untuk setiap mahasiswa, 2) Menentukan mahasiswa yang miskonsepsi, paham konsep, paham konsep tapi kurang yakin, dan tidak tahu konsep, 3) Mentabulasi persentasi mahasiswa yang miskonsepsi, paham konsep, paham konsep tapi kurang yakin, dan tidak tahu konsep pada setiap nomor yang diujikan, 4) Membuat grafik yang melukiskan perbandingan persentasi pada keempat kategori. 


\section{HASIL DAN PEMBAHASAN}

Berdasarkan hasilanalisis data diketahui bahwa sebagian besar mahasiswa mengalami miksonsepsi pada konsep ekologi. Hasil analisis menggunakan metode CRI diketahui bahwa persentase kategori miskonsepsi lebih tinggi daripada kategori lainnya yakni $51.95 \%$. Miskonsepsi terjadi akibat kekeliruan dalam menafsirkan gejala atau fenomena lama yang mereka temukan dalan hidup kesehariannya, dapat berasal dari buku ajar, dan juga bersumber dari guru. Persentase konsepsi mahasiswa secara ringkas dapat digambarkan dalam bentuk diagram batang pada Gambar 1 berikut.

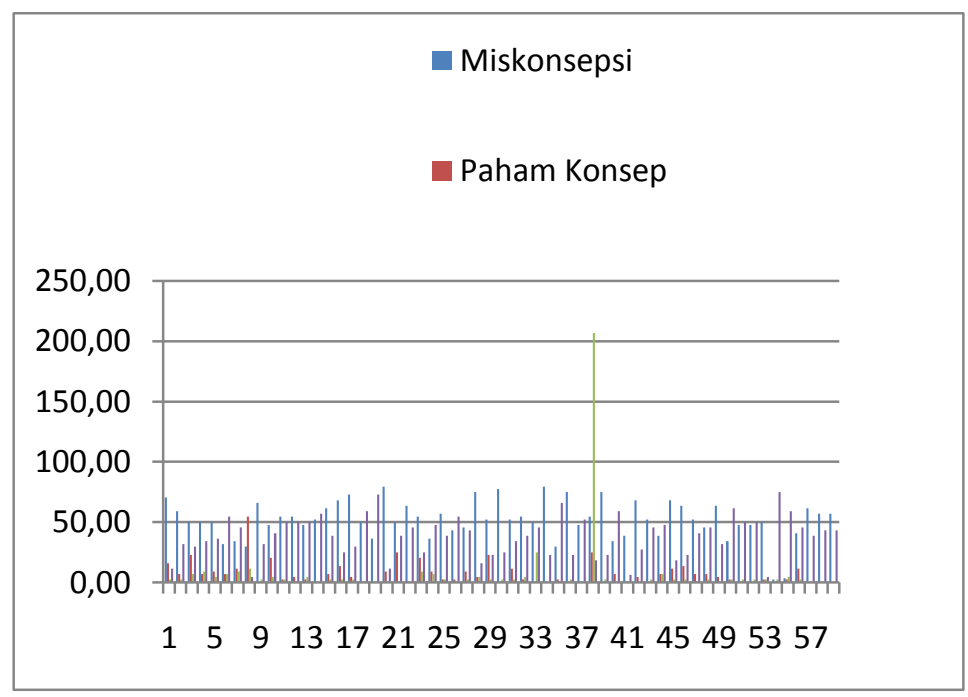

\section{Gambar 1. Diagram batang hasil identifikasi konsepsi siswa}

Diagram batang di atas menunjukkan persentase konsepsi mahasiswa pada konsep ekologi dalam dua indikator yang diuji. Indikator1: Memecahkan masalah ketidakseimbangan lingkungan yang terjadi saat ini melalui kajian pola interaksi antar komponen di dalam ekosistem; Indikator 2: Siswa dapat menjelaskan hubungan antar aliran energi dengan keseimbangan ekosistem. Kedua indikator diuraikan dalam 59 item tes. Dari 59 butir soal yang ditanyakan, teridentifikasi bahwa kategori miskonsepsi menempati urutan tertinggi kecuali pada item nomor 38 tentang konsep rantai makanan, dimana kategori paham konsep kurang yakin (PKKY) menempati urutan teratas.

Dari beberapa subkonsep dalam konsep ekologi dapat dideskripsikan miksonsepsi yang terjadi pada mahasiswa pada bebereapa konsep berikut. Sebagai perwakilan hanya akan dijelaskan beberapa butir soal berikut:

1) Indikator 1: Memecahkan masalah ketidakseimbangan lingkungan yang terjadi saat ini melalui kajian pola interaksi antar komponen di dalam ekosistem. Indikator yang pertama 
diperinci lagi dari nomor 1 sampai nomor 27.Untuk indikator yang pertama subkonsep yang diidentifikasi miskonsepsinya adalah tentang subkonsep ekosistem beserta komponennya, interaksi yang terjadi dalam ekosistem dan kaitan interaksi dengan keseimbangan lingkungan.Persentase tingkatan pemahaman pada subkonsep-subkonsep ini didominasi oleh kategori miskonsepsi dengan rata-rata persentase sebesar.52.44.\%, diikuti dengan tidak tahu konsep 39.14\%, paham konsep 9.84, dan paling rendah paham konsep tapi kurang yakin dengan rata-rata persentase $3.45 \%$. berikut ini akan dibahas, beberapa item yang mewakili indikator pertama.Butir soal 1,4,9,16,23,25. Pada item nomor 1, 4 dan 9, sebagian besar mahasiwa miskonsepsi dalam mmberikan contoh ekosistem.Hal ini disebabkan responden miskonsepsi dalam menentukan komponen-komponen penyusun ekosistem sehingga suatu tempat disebut sebagi suatu ekosistem.Butir soal nomor 16, 23, siswa mengalami miksonsepsi dalam mengaitkan antara interaksi dalam satu ekosistem dengan keseimbangan lingkungan, siswa beranggapan bahwa keseimbngan eksosistem terjadi apabila produsen dengan berbagi varietas lebih dominan dalam suatu eksositem, sedangkan konsumen dalam jumlah sedikit dan dentrivor dipunahkan. Padahal keseimbangan eksosietem dapat terjadi apabila rantai makanan, jaring makanan, dan jumlah spesies seimbang sesuai dengan perannya, baik itu produsen, konsumen maupun dentrivor. Butirsoal 25, siswa mengalami miskonsepsi dalam menyelsaikan masalah yang berkaitan dengankeseimbangan lingkungan, siswa beranggapan bahwa kehilangan salah satu komponen dalam suatu ekosistem seperti produsen tetap dapat menjaga keseimbangan ekosistem padahal sebaliknya, produsen adalah posisi sentral dalam suatu rantai makanan dalam ekosistem karena sebagai pengasil makanan dan sumber oksigen.

2) Indikator 2: Siswa dapat menjelaskan hubungan antar aliran energi dengan keseimbangan ekosistem. Indikator yang kedua diuraikan dari nomor 28 sampai nomor 59. Untuk indikator kedua, subkonsep yang diidentifikasi miskonsepsinya adalah tentang subkonsep rantai dan jaring makanan dalam ekosistem, aliran energi, dan kaitan aliran energi dengan keseimbangan lingkungan. Persentase tingkatan pemahaman pada subkonsep-subkonsep ini didominasi oleh kategori miskonsepsi dengan rata-rata persentase sebesar $51.53 \%$, diikuti dengan tidak tahu konsep 37.55\%, paham konsep tapi kurang yakin 8,95\%, dan paling rendah paham konsep dengan rata-rata persentase $4.62 \%$. Berikut ini akan diuraikan miskonsepsi mahasiwa pada bberapa buitr soal yang mewakili indikator kedua.Butir soal 29, 36, 39, 41, 42 , 59. Indikator ini memuat subkonsep energi, aliran energi dan kaitannya dengan keseimbangan ekosistem. Butir soal 29, 36, dan 39, 41, mahasiswa mengalami miskonsepsi tentang pengertian energi, mahasiswa beranggapan bahwa pengertian dari energi adalah makanan yang membuat tubuh sehat dan beraktivitas, padahal definisi sebenarnya dari energi adalah kemampuan untuk melakukan kerja atau usaha yang tentunya energi ini diperoleh dari sumber-sumber makanan. 
Mahasiswa juga mengalami miskonsepsi pada konsep aliran energi dalam suatu jaring-jaring makanan, mereka beranggapan kehilangan salah satu mata rantai tidak berdampak pada mata rantai makanan lainnya, padahal kelangsungan suatu rantai makanan bergantung dari proses makan di makan antara mata rantai pada tingkatan trofik yang berbeda. dan butir 41 , terjasdi miskonsepsi mengenai jumlah energi pada tingkatan trofik, sebagian besar mahasiwa beranggapan bahwa pada semua tingkat trofik jumlh energi dan jumlah individu adlah sama dan ada juga yang bemahami bahwa semakin naik tingkat trofiknya menujuk puncak piramid amaka jumah energinya semkian besar, padahal semkain naik ke puncak piramida maka jumlah energinya semakin sedikit.Butir soal 42 dan 59, siswa mengalami miskonsepsi pada ketidakseimbangan lingkungan dan cara mengatasinya. Mahasiswa lebih menitikberatkan pemecahan masalah ketidakseimbangan ekosistem dengan cara yang praktis tanpa mengetahui dampak negatifnya pada keseimbngan eksositem, yang diutamakan adalah cepat dan praktis, padahal masalah ketidakseimbangan lingkungan dapat diatasi dengan menempatkan setiap spesies sesuai perannya masing-masing. Sebagai contoh Kabupaten Sumba di serang oleh hama belalang dan mengakibatkan penduduk mengalami kerugian yang sangat parah, solusi yang paling tepat untuk mengatasi permasalahan di atas adalah menyediakan predator asli untuk memangsa hama tersebut, insektisida berdampak pada kerusakan tanah dan menyebabkan munculnya sifat resisten dari hama tersebut.

\section{SIMPULAN}

Berdasarkan hasil temuan dan pembahasan, maka peneliti menyimpulkan bahwa sebagian besar mahasiswa matematika mengalami miskonsepsi pada konsep-konsep ekologi dengan rata-rata persentase mahasiswa yang mengalami miskokonsespi sebesar51.95\%, tidak tahu konsep sebesar 38.28, Paham konsep sebesar10.34\% dan Paham konsep tapi kurang yakin sebesar9,49\%. Sebagian besar Konsep-konsep yang diujikan memberikan dampak kuat pada miskonsepsi, diantaranya ekosistem dan komponenya, interaksi dalam ekosistem dan kaitannya dengan keseimbangan lingkungan, aliran energi dan kaitannya dengan keseimbangan lingkungan serta pemecahan masalah kerusakan lingkungan dengan pendekatan konsep-konsep ekologi.

\section{DAFTAR PUSTAKA}

Ibrahim, M. 2012. Miskonsepsi..

Laksana. 2016. "Miskonsepsi Dalam Materi IPA Sekolah Dasar".Jurnal Pendidikan Indonesia Vol 5, No 2, Halaman 843-852. 
Munawaroh, F dan Falahi, M.D. 2016. "Identifikasi Miskonsepsi Siswa SDN Kemayoran I Bangkalan Pada Konsep Cahaya Menggunakan CRI (Certainty Of Response Index)”. Jurnal Pena Sains Vol 3, No 1, Hal 69-76.

Murni, D. 2013. "Identifikasi Miskonsepsi Mahasiswa Pada Konsep Substansi Genetika Menggunakan Certainty of Response Index (CRI)". Prosisding Semirata FMIPA Universitas Lampung, 2013. hal 205-211.

Mustaqim, T.A, Zulfiani, Herlanti, Y. 2014. "Identifikasi Miskonsepsi Siswa dengan Menggunkana metode Certainty of Response Index (CRI) Pada Konsep Fotosintesis dan Respirasi Tumbuhan”. Edusains Vol VI No. 02 Tahun 2014 halaman 146-152.

Saleem,H et al. 1999. "Misconception and The Certainty of Response Index (CRI)". Physics Education 34 (5).

Tayubi, Y.R. 2005. "Identifikasi Miskonsepsi Pada Konsep-Konsep Fisika Menggunakan Certainty of Response Index (CRI)". Mimbar Pendidikan No.3/XXIV/2005 Halaman 4-9. 